\title{
Factors associated with Leptospira sp infection in a large urban center in northeastern Brazil
}

\author{
Fatores associados à infecção por Leptospira sp \\ em um grande centro urbano do Nordeste do Brasil
}

\author{
Juarez Pereira Dias ${ }^{1}$, Maria Glória Teixeira ${ }^{1}$, Maria Conceição Nascimento Costa ${ }^{1}$, \\ Carlos Maurício Cardeal Mendes ${ }^{1}$, Patrícia Guimarães ${ }^{2}$, Mitermayer Galvão Reis ${ }^{2}$, \\ Albert $\mathrm{Ko}^{2,3}$ and Maurício Lima Barreto ${ }^{1}$
}

\begin{abstract}
Leptospirosis is a zoonotic disease that has emerged to cause epidemics in urban communities in developing countries. However, little is known about the infection in the general population. A seroprevalence survey was performed on a random sample of 1,390 subjects in Salvador, Brazil. Data on environmental and socioeconomic factors were collected. The microagglutination test of serum samples was used to show any prior Leptospira infection. The overall seroprevalence was 12.4\%. Among the seropositive individuals, 111 (61\%) had high titers for serovars of the Icterohaemorrhagiae serogroup. Seroprevalence increased with age and was similar for males and females. A positive correlation between Leptospira infection and low educational level was found. These findings indicate that a significant proportion of this urban population is exposed to pathogenic Leptospira. Public health actions for leptospirosis control will need to target not only the traditional groups at risk of infection with severe forms of this disease, but also the general population that is at risk.
\end{abstract}

Key-words: Leptospirosis. Seroprevalence. Epidemiology. Urban epidemics.

\section{RESUMO}

A leptospirose é uma zoonose que tem emergido causando epidemias em comunidades urbanas de países em desenvolvimento. Entretanto, pouco é conhecido sobre infecção na população geral. Inquérito de soroprevalência foi realizado em amostra randômica de 1.390 indivíduos de Salvador, Brasil. Dados sobre fatores ambientais e sócio-econômicos foram coletados. Teste de Microaglutinação de amostras de soro foi utilizado para evidenciar infecção anterior por Leptospira. Soroprevalência global foi 12,4\%. Entre os soropositivos, 111 (61\%) tinbam altos títulos para os sorovares do serogrupo Icterohaemorrhagiae. A soroprevalência aumentou com a idade e foi similar entre homens e mulheres. Encontrou-se correlação positiva entre infecção por Leptospira e baixo nivel educacional. Os achados indicam que significativa proporção dessa população urbana está exposta a Leptospira patogênica. Ações de saúde pública para controle desta doença necessitarão ter como alvo não só os tradicionais grupos de risco associados às suas formas graves, como também a população geral sob risco.

Palavras-chaves: Leptospirose. Soroprevalência. Epidemiologia. Epidemias urbanas

Leptospirosis is a zoonotic disease of global importance ${ }^{416}$. In many countries, the disease is restricted to specific occupational groups, such as sewage system workers, mine workers, wetland agriculturists, soldiers and abattoir workers dealing with bovine meat, among others ${ }^{1825}$ However, in the large urban centers of tropical developing countries ${ }^{9172} 31$, leptospirosis affects not only occupational risk groups but also the general population'.
Transmission is closely related to environmental factors ${ }^{2} 151727$, such that inadequate sanitary and rainwater sewage systems and waste accumulation favor human contact with the excreta from animal reservoirs ${ }^{17} 2027$.

In Brazil, annual epidemics occur in major urban centers such as São Paulo, Rio de Janeiro, Salvador and Recife, during seasonal periods of flooding and heavy rainfall ${ }^{2} 61728$. Nationwide, more

\footnotetext{
1. Instituto de Saúde Coletiva, Universidade Federal da Bahia, Salvador, BA. 2. Centro de Pesquisas Gonçalo Moniz, Fundação Oswaldo Cruz/Ministério da Saúde, Salvador, BA. 3. Division of International Medicine and Infectious Disease, Weill Medical College of Cornell University, New York, USA

Support: Secretaria de Desenvolvimento Urbano do Estado da Bahia, PRONEX/MCT-CNPq (Contract no. 661086/1998-4); CENEPI/FUNASA/MS and the National Institutes of Health, USA (TW00919-07 and AI052473-01A1)

Address to: Dr. Juarez Pereira Dias. Instituto de Saúde Coletiva/UFBA. Basílio da Gama s/nº, Campus Universitário do Canela, 41110-040 Salvador, BA, Brasil.

Tel: $55713383-7412$; Fax: $55713283-7460$.

e-mail: jucadias09@uol.com.br

Recebido para publicação em: 18/08/2006

Aceito em: 17/08/2007
} 
than 10,000 suspected cases are reported each year. Between 1987 and 1997, 32,436 of these reported cases were confirmed by laboratory tests. On the basis of confirmed cases, the annual incidence has been as high as 2.1 cases per million population. Population-based surveillance in the city of Salvador found that the infection rate for severe leptospirosis was 12.5 cases per 100,000 inhabitants during a single epidemic season ${ }^{17}$. The mortality rate among cases identified during this epidemic was $15 \%$.

However, information from hospital-based surveillance in Brazil $^{617}$ significantly underestimates the impact of urban leptospirosis. Severe leptospirosis is believed to account for a fraction (5-15\%) of all clinical infections ${ }^{13}$. Furthermore, serological surveys have been restricted to evaluating traditional risk groups $^{1932}$. Hence, there is limited understanding of the seroprevalence of infection and circulation of pathogenic Leptospira among the general urban population. Identification of factors that take part in the dynamics of the circulation of Leptospira among the general population, such as environmental transmission factors, may contribute towards improving current knowledge of the epidemiology of urban leptospirosis and towards drawing up policies and interventions aimed at controlling this emerging health problem.

A citywide survey in Salvador, Brazil, was performed in 1998 to evaluate the health impact of a large-scale intervention aimed at improving the sanitary infrastructure of the city. Through retrospective evaluation of the serum samples obtained during this survey, we had the opportunity to determine the prevalence of Leptospira infection in the population of Salvador and identify possible environmental, socioeconomic and biological factors associated with prior infection.

\section{MATERIAL AND METHODS}

Setting and population. This study was conducted in Salvador, a city of 2.3 million inhabitants. Although the main water supply network served more than $90 \%$ of households at the time of the study, only $22 \%$ were connected to the main sanitary sewage network $^{19}$. Despite $77 \%$ of the population having access to some form of garbage collection, there was significant variation in the access to this service among different areas in the city. This study was performed as part of an evaluation to determine the impact of a large-scale project (Projeto Babia Azul) to improve the sanitation infrastructure of Salvador ${ }^{3}$. The evaluation studies were performed in 30 sentinel sites in ten selected sewage drainage basins (Figure 1) that had been selected through a previous study by Teixeira, 2002 ${ }^{29}{ }^{30}$. The population-based sample included 1,390 subjects selected by simple random sampling, without reposition ${ }^{7}$, from among the 68,749 residents in the ten sewage drainage basins. The study subjects were enrolled between May and July 1998, in accordance with informed consent procedures. The study protocol was approved by the Research Ethics Committee of the Gonçalo Moniz Research Center, Oswaldo Cruz Foundation, an entity linked to the Brazilian Ministry of Health.

Data collection. After enrollment, a questionnaire was administered at an interview to obtain demographic data (name, address, gender and age), socioeconomic data (income and schooling) and information on environmental characteristics (garbage collection and storage, contact with rodents, flooding of household and surroundings and water supply frequency). In addition, the environmental status in loco was surveyed as part of the Projeto Bahia Azul evaluation, to obtain information on water supply, sanitary sewage and rainwater drainage systems, flooding and garbage collection frequencies and disposal points.

Serologic case confirmation. The microagglutination test (MAT) was used to detect anti-Leptospira antibodies in the subjects' serum samples ${ }^{11}$. Six reference strains (Leptospira interrogans serovar Copenhageni strain M20, serovar Icterohaemorrhagiae strain RGA, serovar Canicola strain Hond Utrecht IV and serovar Autumnalis strain Autumnalis; Leptospira kirchneri serovar Cynopteri strain Cynopteri; and Leptospira biflexi serovar Patoc strain Patoc 1) and three clinical isolates (Leptospira interrogans serovar Copenhageni strain Fiocruz L1-130, serovar Canicola strain Fiocruz L1-133 and serovar Hurstbridge strain L1-125)

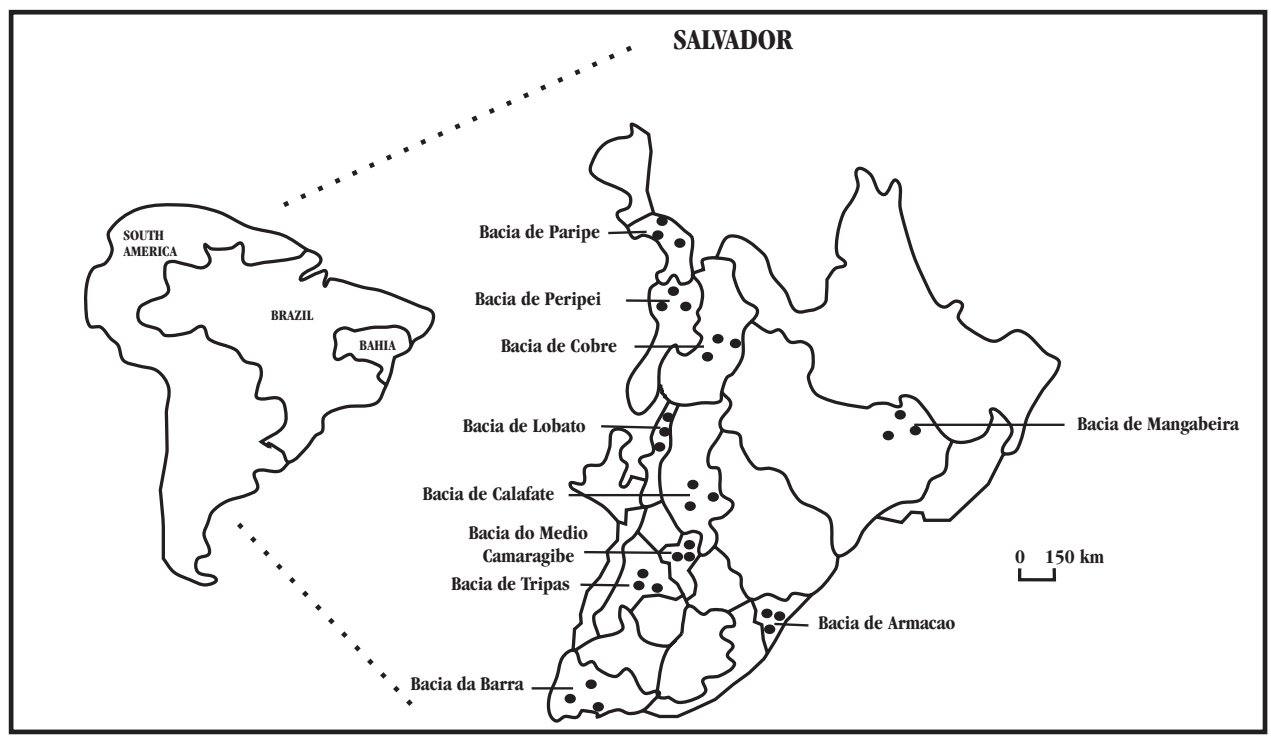

Figure 1 - Geographical location of the city of Salvador in Brazil and the 10 sewage drainage basins within Salvador which were used as sentinel sites for the study, 1998. 
obtained from patients during surveillance in Salvador ${ }^{17}$ were used. These represented a total of six serogroups (Autumnalis, Canicola, Icterohaemorrhagiae, Cynopteri, Patoc and Hurstbridge). The cross-absorption agglutination test and monoclonal antibody methods were used beforehand to determine the serovar status for the clinical isolates, at the WHO Collaborative Laboratory for Leptospirosis (Royal Tropical Institute, Amsterdam, Holland) and Oswaldo Cruz Foundation (Salvador, Brazil). Prior isolation studies from clinical cases found that the serovar Copenhageni was the principal agent for outbreaks in Salvador ${ }^{1727}$. The use of this reduced serovar battery accounted for $98 \%$ of the positive agglutination reactions when an expanded 25-serovar battery was used to evaluate samples from leptospirosis patients identified during surveillance in Salvador ${ }^{1727}$. MAT titers of $\geq 1: 50$ in relation to strains belonging to pathogenic serogroups were defined as evidence for prior Leptospira infection.

Statistical analysis. The statistical analysis of individual-level data included stratification of crude and age-adjusted prevalences of prior Leptospira sp. infection according to biological, social, economic, social and environmental characteristics of subjects and calculation of their respective prevalence ratios (PR) and 95\% confidence intervals (CI). The chi-squared test was used to evaluate trends relating to prior Leptospira infection among different strata of environmental conditions. Linear regression analysis was used to assess the relationship between Leptospira seroprevalence and age. The association between reported sightings of rats in the household environment and seropositivity was evaluated using logistic regression, which allowed socioeconomic and environmental variables to be treated as potential confounders and effect modifiers.

Ecological-level analysis was performed using the sewage drainage basins as the analysis unit. The seroprevalence of Leptospira sp was correlated with variables that included the proportions of male subjects, subjects aged 15 years and over, subjects with less than 8 years of schooling (among those aged 15 years and over), households with incomes of less than two minimum monthly salaries and subjects who reported the presence of rodents, garbage collection, flooding of household and surroundings and access to an enclosed piped water source in the household. Crude prevalence and age-adjusted prevalences were estimated for each sentinel area and each sewage drainage basin $^{21}$. An indirect approach was used for seroprevalence rate standardization according to age, using the sample population rates as a basis. Prevalence ratios (PR) and Spearman's rank correlation coefficients ( $r$ ) were calculated in order to test for associations. The specific seroprevalence was calculated for exposure to the serogroup Icterohaemorrhagiae, which was the principle etiological agent for leptospirosis in Salvador ${ }^{17}$.

\section{RESULTS}

Of the 1,390 subjects studied, $58.3 \%$ were female, $56.5 \%$ had an educational level corresponding to incomplete basic schooling ( $1^{\text {st }}-8^{\text {th }}$ grades $), 26.3 \%$ reported a family income of less than US $\$ 45$ per month and $74.7 \%$ were 15 years old and over (Table 1 ). Among these subjects, 172 presented evidence for prior Leptospira infection according to the microagglutination test. The overall seroprevalence was $12.4 \%$ (95\% CI: $10.7-14.2)$. There was no statistically significant difference between the proportions of prior Leptospira infection in male and female subjects (14.0 vs $11.2 \%$; $\mathrm{p}=0.127)$. The prevalence of prior infection was associated with increasing age among the subjects $(\beta=0.024, \mathrm{p}=0.00)$ (Figure $2)$. The group aged 15 years old and over had a risk of infection that was 2.2 times greater ( $95 \%$ CI: 1.44-3.35) than the risk among those under 15 years old (Table 1). However, it is worth noting that the group under 15 years of age had a prevalence of infection of $6.5 \%$ (95\% CI: 4.27-9.78) (Table 1). The seroprevalence was inversely associated with increased schooling $\left(\chi^{2}\right.$ trend $\left.=6.93 ; \mathrm{p}=0.039\right)$ and income levels $\left(\chi^{2}\right.$ trend $\left.=6.93 ; \mathrm{p}=0.008\right)$. Leptospira infection was not significantly associated with access to piped water, reported sightings of rats, presence of uncollected garbage or flooding around the household (Table 1).

The seroprevalence rates did not differ significantly among subjects living in the 10 sewage drainage basins within Salvador

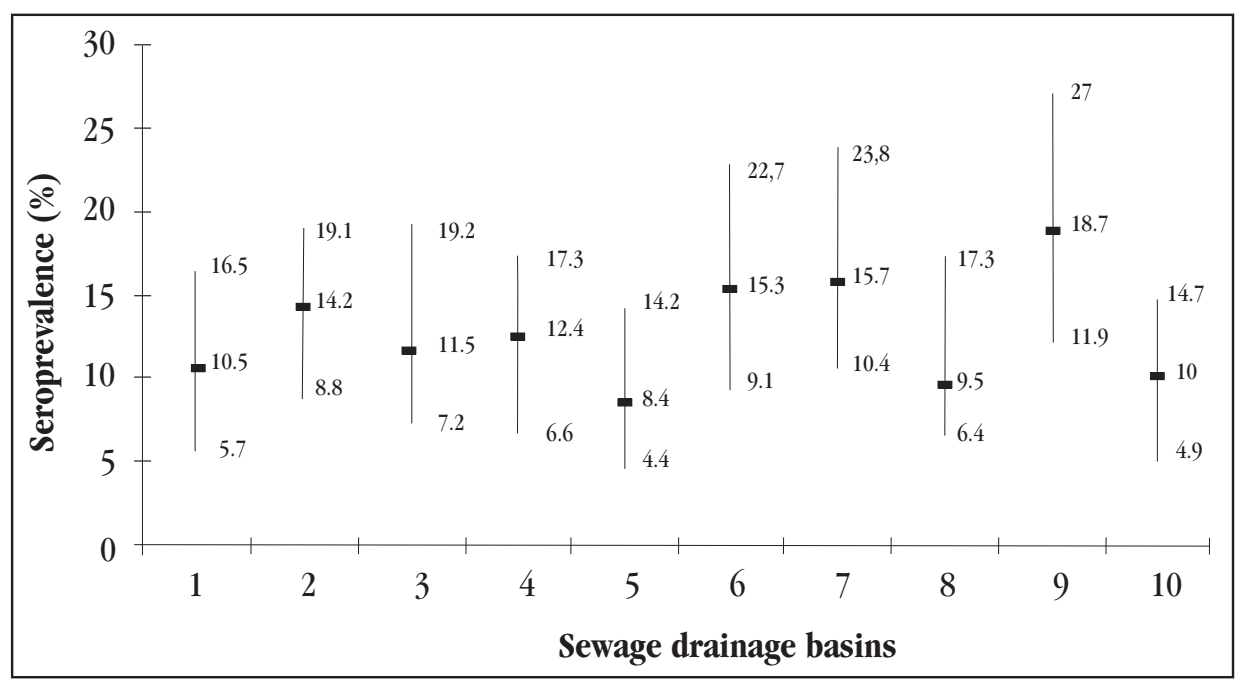

Figure 2 - Adjusted seroprevalence of Leptospira infection and 95\% confidence intervals according to sewage drainage basins in Salvador, Brazil, 1998. 
Table 1 - Prevalence of Leptospira infection according to subject characteristics. Salvador, Babia, Brazil, 1998.

\begin{tabular}{|c|c|c|c|c|c|}
\hline \multirow[t]{2}{*}{ Variables } & \multirow{2}{*}{$\begin{array}{c}\text { Total } \\
\text { responses }\end{array}$} & \multicolumn{2}{|c|}{ Seropositive } & \multirow[t]{2}{*}{ PR } & \multirow[t]{2}{*}{$95 \%$ CI } \\
\hline & & $\mathrm{n}^{0}$ & $\%$ & & \\
\hline \multicolumn{6}{|l|}{ Gender } \\
\hline male & 580 & 81 & 14.0 & 1.24 & $0.94-1.64$ \\
\hline female & 810 & 91 & 11.2 & - & 1.0 \\
\hline \multicolumn{6}{|l|}{ Age (years) } \\
\hline$\geq 15$ & 1,038 & 149 & 14.3 & 2.20 & $1.44-3.35$ \\
\hline$<15$ & 352 & 23 & 6.5 & - & 1.0 \\
\hline \multicolumn{6}{|l|}{ Education level } \\
\hline university & 47 & 4 & 8.5 & - & 1.0 \\
\hline high school ( $9^{\text {th }}-11^{\text {th }}$ grades) & 291 & 30 & 10.3 & 1.19 & $0.44-3.24$ \\
\hline basic schooling $\left(1^{\mathrm{st}}-8^{\text {th }}\right.$ grades $)$ & 861 & 119 & 13.8 & 1.55 & $0.60-4.03$ \\
\hline no schooling & 54 & 13 & 24.1 & 2.47 & $0.86-7.14$ \\
\hline \multicolumn{6}{|l|}{ Household income } \\
\hline$>8 \mathrm{mms}$ & 135 & 12 & 8.9 & - & 1.0 \\
\hline$\leq 8$ and $>5 \mathrm{mms}$ & 133 & 9 & 6.8 & 0.78 & $0.34-1.79$ \\
\hline$\leq 5$ and $>2 \mathrm{mms}$ & 695 & 81 & 11.7 & 1.28 & $0.72-2.28$ \\
\hline$<2 \mathrm{mms}$ & 427 & 70 & 16.4 & 1.73 & $0.96-3.09$ \\
\hline \multicolumn{6}{|l|}{ Reported flooding in the household } \\
\hline yes & 527 & 69 & 13.1 & 1.10 & $0.82-1.46$ \\
\hline no & 863 & 103 & 11.9 & - & 1.0 \\
\hline \multicolumn{6}{|l|}{ Access to piped water } \\
\hline regular & 718 & 89 & 12.4 & 1.0 & $0.76-1.33$ \\
\hline irregular & 672 & 83 & 12.3 & - & 1.0 \\
\hline
\end{tabular}

Reported presence in home environment or home surrounds of: rats

\begin{tabular}{lrrrrc} 
yes & 241 & 28 & 11.6 & 0.93 & $0.63-1.36$ \\
no & 1,149 & 144 & 12.5 & - & 1.0 \\
solid garbage & & & & & \\
$\quad$ yes & 848 & 111 & 13.1 & 1.16 & $0.87-1.56$ \\
no & 542 & 61 & 11.3 & - & 1.0 \\
\hline PR: prevalence rates & \multicolumn{5}{c}{ mms: minimum monthly salary = US 45 } \\
95\% CI: 95\% confidence intervals
\end{tabular}

(Figures 1 and 3). The sewage drainage basins with the lowest and highest proportions of seropositive subjects (basins 5 and 9; adjusted proportions of $8.4 \%$ and $18.7 \%$ respectively) were the regions with poorest socioeconomic conditions. Sewage drainage basin 8 , the area with the highest socioeconomic level, had an adjusted seroprevalence of $9.5 \%$.

Ecological analyses found that age-adjusted seroprevalence was associated with the proportion of adults with less than 8 years of schooling ( $\mathrm{r}=0.782 ; \mathrm{p}=0.008)$ (Table 2). The environmental characteristics relating to previously reported risk factors for urban leptospirosis, such as flooding and reporting of rats, were also significantly associated with increased age-adjusted seroprevalence rates.

Among the 172 subjects with anti-Leptospira antibodies (MAT titer $\geq 1: 50), 111(64.5 \%)$ presented their highest agglutination titers against reference serovars belonging to the Icterohaemorrhagiae serogroup. The highest MAT titers were against reference serovars belonging to the Canicola serogroup, which is associated with Leptospira carried in dogs, in six (3.5\%)

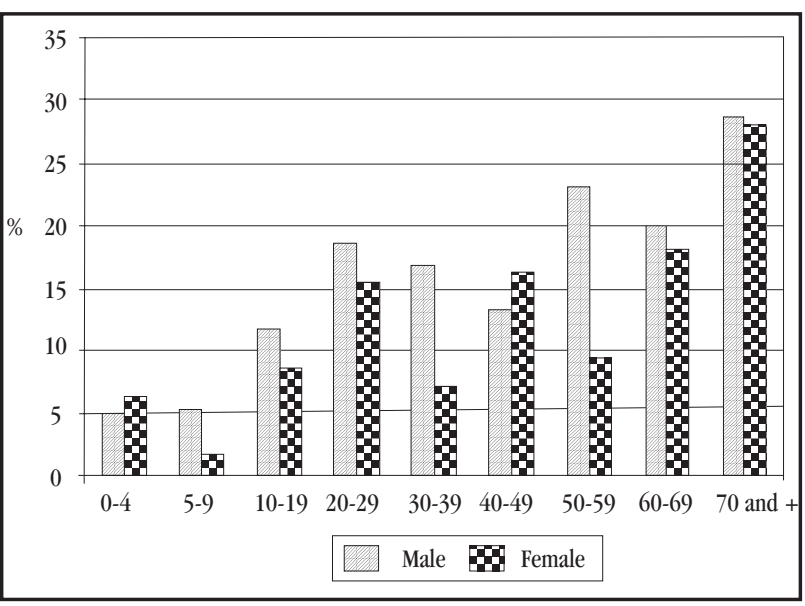

Figure 3 - Prevalence (\%) of prior Leptospira infection according to sex and age group. Salvador, Brazil, 1998.

of the 172 seropositive subjects. The other 61 (35.5\%) subjects subjects had highest MAT titles against the other five pathogenic serovars. The prevalence of seropositive subjects whose highest agglutination titers were against the Icterohaemorrhagiae

Table 2 - Correlation coefficients for the association between ageadjusted seroprevalence of Leptospira sp infection and selected variables. Salvador, Babia, Brazil, 1998*.

\begin{tabular}{|c|c|c|}
\hline Variable & $\begin{array}{c}\text { Correlation } \\
\text { coefficients (r) }\end{array}$ & $\mathrm{p}$ \\
\hline Male (\%) & 0.036 & 0.920 \\
\hline Mean age & -0.176 & 0.627 \\
\hline Schooling $(\%)^{1}$ & 0.782 & 0.008 \\
\hline Family $(\%)^{2}$ & -0.480 & 0.160 \\
\hline Reported rats $(\%)^{3}$ & 0.146 & 0.688 \\
\hline Reported garbage $(\%)^{4}$ & -0297 & 0.405 \\
\hline Reported flooding $(\%)^{5}$ & 0.298 & 0.403 \\
\hline
\end{tabular}

* The analysis unit was 10 sewage drainage basins

1. Percentage of population with $<8$ years of schooling among subjects aged 15 years and over.

2. Percentage of family income $\leq 2$ minimum monthly salaries.

3. Percentage of interviewed population who reported presence of rats in the environment surrounding the home.

4. Percentage of interviewed population who reported presence of accumulated garbage in the environment surrounding the home.

5. Percentage of interviewed population who reported flooding in the home and its surroundings.

serogroup did not differ significantly between sewage drainage basins and was not associated with poor environmental characteristics (data not shown).

\section{DISCUSSION}

The Leptospira seroprevalence observed in Salvador indicates that this agent has wide circulation in this city, regardless of sanitation conditions or socioeconomic situation. However, individual and ecological analysis showed that Leptospira sp was inversely associated with education level. The seroprevalence (12.4\%) observed in Salvador was lower than what has been reported from other regions of Brazil ${ }^{24}$ and other developing 
countries $^{19}$, where it ranged from 25.0 to $54.2 \%$. It should be noted, however, that the highest levels have been reported among selected populations living in high-risk areas where leptospirosis is hyperendemic or where there is a high degree of exposure. The relatively low seroprevalence rate observed in Salvador, a City where the incidence of clinical severe leptospirosis is high (10 per 100,000 population), may reflect the association of severe disease with Icterohaemorrhagiae serogroup infection ${ }^{12}$. In Salvador, nearly two thirds of the Leptospira infections were due to the Icterohaemorrhagiae serogroup, and the frequency was slightly higher in poor areas.

It can therefore be inferred that in this city there was frequent and widespread exposure to Rattus norvegicus, which is the primary reservoir for leptospirosis in the urban environment ${ }^{12}$. This finding is further supported by the large (65\%) proportion of seropositive individuals who had their highest MAT titers against strains belonging to Icterohaemorrhagiae, which is the serogroup most associated with the domestic rat reservoir.

Despite the absence of significant differences between areas with regard to overall seroprevalence, higher proportions of MAT seroreactivity to the pathogenic serogroup Icterohaemorrhagiae were found among subjects living in the sewage drainage basins with the poorest socioeconomic conditions. This may partially explain the greater frequency of clinically severe cases in these areas of the city, as reported recently by Ko et al ${ }^{17}$ and previously in the 1970 s by Caldas \& Sampaio ${ }^{6}$. Alternatively, poor urban slum residents may be subjected to more intense exposure to pathogenic Leptospira. The great majority of clinical cases occur during the rainy season, in the middle of each year, due to the lack of drainage systems in these poorer areas. The water accumulations temporarily formed are an ideal environment for proliferation of the leptospires contained in the urine of Rattus norvegicus ${ }^{18}$. During the rainy season, the populations in these poor areas experience frequent contact with environmental sources of contamination such as flooding and sewage water in the household or workplace setting ${ }^{927}$ without access to adequate protection such as shoes and boots. This exposure may produce infections with higher inoculum levels and, in turn, impart a greater risk of developing severe clinical outcomes following infection ${ }^{10}$. Studies that found a strong positive association between seroprevalence and the habit of walking barefoot ${ }^{1023}$, and also the greater risk observed in the present investigation among subjects with low levels of schooling, also strengthen this explanation. The fact that Leptospira interrogans Icterobaemorrhagiae was the most prevalent serogroup among the study subjects suggests that infection by leptospires that are known to cause severe disease forms may also produce a high proportion of subclinical or non-apparent infections ${ }^{22}$.

Men and women were equally exposed to Leptospira infection in the present study, and this was also found in other studies ${ }^{22} 24$. The lack of gender-specific differences in seroprevalence contrasts markedly with what was observed regarding the risk of acquiring severe clinical leptospirosis. In Salvador, men represented 80\% of the reported cases of severe leptospirosis identified by active surveillance ${ }^{17}$. Together, these findings provide further evidence to suggest that inoculum dose factors play a role in the progression of infection to clinical disease. Occupation was not identified as a risk factor for infection in this study. However, it must be noted that, in agreement with the findings in the literature ${ }^{10}$, the present study found that men of productive age (21-50 years) had greater seroprevalence than women did, although this difference was not statistically significant.

While no significant associations between environmental factors and Leptospira seroprevalence were found in the present study, the results allow the inference that the current sanitation infrastructure in Salvador has not been sufficient to prevent widespread environmental contamination with pathogenic leptospires, since high seroprevalence was observed even in areas considered to have adequate sanitation. The findings from this study provide support for the need for focused environmental sanitation programs using strategies for controlling urban rodent populations and their habitats, which in turn could reduce the contact between pathogenic Leptospira and humans.

\section{ACKNOWLEDGEMENT}

The authors acknowledge the laboratory assistance provided by Patrícia Guimarães.

\section{REFERENCES}

1. Almeida PA, Martins LFS, Brod CS, Germano ML. Levantamento soroepidemiológico de leptospirose em trabalhadores do serviço de saneamento ambiental em localidade urbana da região sul do Brasil. Revista de Saúde Pública 28: 76-81, 1994.

2. Barcellos C, Sabroza PC. The place venid the case: leptospirosis risk and associated environmental conditions in a flood-related outbreak in Rio de Janeiro. Cadernos de Saúde Pública 17: 59-67, 2001.

3. Barreto ML, Strins A, Prado M, Costa MC, Teixeira MG, Martins Jr D, Pereira JJ, Oliveira A. Saneamento básico: impacto epidemiológico do Programa Bahia Azul. Bahia: Análise \& Dados 7: 24-38, 1997.

4. Bharti AR, Nally JE, Ricaldi JN, Matthias MA, Diaz MM, Lovett MA, Levett PN, Gilman RH, Willig MR, Gotuzzo E, Vinetz JM. Leptospirosis: a zoonotic disease of global importance. The Lancet Infectious Diseases 3: 757-771, 2003.

5. Levett PN. Leptospirosis. Clinical Microbiology Reviews 14: 296-326, 2001.

6. Caldas EM, Sampaio MB. Leptospirosis in the city of Salvador, Bahia, Brasil. International Journal of Zoonoses 6: 85-96, 1979.

7. Cochran WG. Sampling Techniques. $3^{\text {rd }}$ edition, John Wills \& Sons, New York, 1977.

8. Dastis-Bendala C. Manzanares-Torne L, Perez-Lozano MJ, Cano-Fuentes G, Vargas-Romero J, Pumarola-Sune T. Prospective serological study of leptospirosis in Southern Spain. European Journal of Epidemiology 12: 257-262, 1996.

9. Dupont H, Dupont-Perdrizet D, Perie Jl, Zehner-Hansen S, Jarrige B, Daijardin JB. Leptospirosis: Prognostic Factors Asssociated with Mortality. Clinical Infectious Diseases 25: 720-724, 1997.

10. Everard COR, Fraser-Chanpong, Everard JD. The incidence of severe leptospirosis in Trinidad. Tropical and Geographical Medicine 39: 126-132, 1987.

11. Faine $S$. Guidelines for the control of leptospirosis. World Health Organization Offset Publication. World Health Organization № 67, Geneva, 1982.

12. Faine S. Leptospira and Leptospirosis. CRS Press, Baton Ranton, 1993.

13. Farr RW. Leptospirosis. Clinical Infectious Diseases 21:1-6, 1995.

14. Instituto Brasileiro de Geografia e Estatística - Censo Demográfico, Rio de Janeiro, p.1-600, 1991.

15. Johnson MAS, Smith H, Joseph P, Gilman RH, Bautista CT, Campos KJ, Cepedes M, Klatsky P, Vidal C, Terry H, Calderon MM, Coral C, Cabrera L, Parmar PS, 
Vinetz JM. Environmental Exposure and Leptospirosis, Peru. Emerging Infectious Diseases 10: 1016-1022, 2004

16. Katz AR, Ansdell VE, Effler PV, Middleton CR, Sasaki DM. Leptospirosis in Hawaii, 1974-1998: Epidemiologic analysis of 353 laboratory-confirmed cases. American Journal of Tropical Medicine and Hygiene 66: 61-70, 2002.

17. Ko AI, Reis MG, Dourado CMR, Johnson WD, Riley LW. Urban epidemic of severe leptospirosis in Brazil. The Lancet 354: 820-825, 1999.

18. Lilembaum W, Ribeiro V, Martin E, Bispo V. Estudo sorológico para detecção de anticorpos anti-leptospira em Rattus norvegicus de Duque de Caxias, Rio de Janeiro, Brasil. Revista Latino Americana de Microbiologia 35: 357-360, 1993.

19. Macedo NA. Aglutininas anti-leptospira em soros humanos do Estado do Piauí, com particular referência aos aspectos ocupacionais. 1994 a 1996. Tese de Doutorado, Universidade de São Paulo, São Paulo, SP, 1997.

20. Martins FSV, Castiñeiras TMPP. Leptospirose. In: Schechter M, Marangoni DV (eds) Doenças Infecciosas, condutas diagnósticas e terapêuticas, $2^{a}$ edição, Rio de Janeiro, p. 145-152, 1998.

21. Milroy C, Borja PC, Barros FR, Barreto ML. Evaluating sanitary quality and classifying urban sectors according to environmental conditions. Environment \& Urbanization 13: 235-256, 2001

22. Morshed MG, Konishi H, Terada Y, Nakazawa T. Seroprevalence of leptospirosis in a rural flood prone district of Bangladesh. Epidemiology and Infection 112: 527-531, 1994

23. Murhekar AP, Sugunan P, Vijjayachari P, Sharma S, Sehgal SC. Risk factors in the transmission of leptospiral infection. Indian Journal of Medicine Research 107: 218-223, 1998.
24. Pereira MM, Andrade J. Human Leptospirosis in a slum area in the city of Rio de Janeiro, Brazil - a serological and epidemiological study. Memórias do Instituto Oswaldo Cruz 85: 47-52,1990.

25. Russeli KL, Gonzalez MAA, Watts DM, Lagos-Figueroa RC, Chauca G, Ore M, Gonzales JE, Moron C, Tesh RB, Vinetz JM. An outbreak of Leptospirosis among Peruvian Military Recruits. The American Journal of Tropical Medicine and Hygiene 69: 53-57, 2003.

26. Sanchez, EM, La Paz RC, Acosta CL. Algunas consideraciones sobre el comportamiento de la leptospirosis humana en Cuba. Revista Cubana Medicina Tropical 45: 32-41, 1993.

27. Sarkar U, Nascimento SF, Barbosa R, Martins R, Nuevo H, Kalafanos I, Grunstein I, Flannery B, Dias J, Riley LW, Galvão Reis M, Ko IA. A population-based casecontrol investigation of risk factors for leptospirosis during an urban epidemic The American Journal of Tropical Medicine and Hygiene 66: 605-610, 2002.

28. Souza D. Considerações sobre enchentes e leptospirose humana no município de São Paulo. Revista da Escola de Enfermagem da Universidade de São Paulo 20: $243-250,1986$

29. Teixeira MG, Barreto ML, Costa MCN, Ferreira LDAF, Vasconcelos PFC, Cairncross S. Dynamics of dengue virus circulation: a silent epidemic in complex urban area. Tropical Medicine \& International Health 7: 757-762, 2002.

30. Teixeira MG, Barreto ML, Costa MCN, Strina A, Martins Jr D, Prado M. Sentinel areas: a monitoring strategy in public health. Cadernos de Saúde Pública 18: 1189-1195, 2002.

31. Vinetz JM. Leptospirosis. Current Opinion in Infectious Diseases 14: 527-538, 2001.

32. Zamora JB, Riedemann SG, Montecinos AI, Cabezas XO. Enquesta serologica de leptospirosis humana em ocupaciones de alto riesco em Chile. Revista Médica de Chile 118: 247-252, 1990 